Nafia Umaroh, Analisis boraks dan uji organoleptik...

\title{
ANALISIS BORAKS DAN UJI ORGANOLEPTIK PADA BERBAGAI IKAN ASIN YANG DIJUAL DI PASAR
}

\author{
Nafia Umaroh dan Ani Sulistyarsi \\ Program Studi Pendidikan Biologi, FPMIPA, IKIP PGRI MADIUN \\ Email : \\ Fialala18@Gmail.com \\ anismasa81@yahoo.com
}

\begin{abstract}
ABSTRAK
Tujuan penelitian adalah untuk mengetahui kandungan boraks dan uji organoleptik pada ikan asin yang beredar di pasaran dengan jenis gerih abang, gerih balur dan teri

Penelitian ini berbentuk penelitian deskripstif kualitatif. Uji kadar boraks menggunakan metode titrasi volumetri. Uji organoleptik tingkat kesukaan masyarakat dilihat melalui uji warna, aroma dan tekstur dari ikan asin dengan menggunakan angket. Pengisian angket organoleptik masyarakat (ibu rumah tangga) dilakukan di Desa Klampisan, Kecamatan Geneng, Kabupaten Ngawi dan mahasiswa dilakukan di kampus IKIP PGRI Madiun.

Hasil penelitian kadar boraks tertinggi pada ikan asin jenis teri (C2) yaitu 3,69\% dengan nilai organoleptik 72,6 dan kadar boraks terendah pada ikan asin jenis gerih balur (B2) yaitu $1,21 \%$ dengan nilai organoleptik 74,8 .
\end{abstract}

Kata Kunci :Ikan Asin, Zat Aditif Makanan, Boraks, Organoleptik

\section{PENDAHULUAN}

Proses pengelolaan makanan selalu diusahakan untuk menghasilkan produk makanan yang disukai dan berkualitas baik. Penambahan Bahan Tambahan Makanan (BTM) sering dilakukan pada proses pembuatan makanan dengan tujuan untuk mendapatkan produk seperti yang diinginkan, bahan tambahan makanan yang digunakan disebut food additive (Widyaningsih dalam Imee, 2012: 1). Bahan tambahan makanan adalah bahan atau campuran bahan yang secara alami bukan merupakan bagian dari bahan baku pangan, tetapi ditambahkan pada pangan untuk mempengaruhi sifat atau bentuk makanan, hal tersebut menyebabkan zat gizi yang terkandung dalam makanan menjadi berkurang. Penambahan bahan tambahan/zat aditif ke dalam makanan merupakan hal yang dipandang perlu bagi produsen untuk meningkatkan mutu dan kualitas suatu produk sehingga mampu bersaing di pasaran. Bahan tambahan makanan yang digunakan untuk menjaga kualitas makanan tersebut salah satunya dengan menambahkan bahan kimia berjenis boraks. Boraks atau yang lazim disebut asam borat (boric acid) adalah senyawa kimia turunan dari logam berat boron (B). Boraks atau asam borat terdiri atas tiga macam senyawa, yaitu: asam ortoborat $\left(\mathrm{H}_{3} \mathrm{BO}_{3}\right)$, asam metaborat $\left(\mathrm{HBO}_{2}\right)$, dan asam piroborat $\left(\mathrm{H}_{2} \mathrm{~B}_{4} \mathrm{O}_{7}\right)$. Boraks bersifat antiseptik sehingga sering dimanfaatkan sebagai pengawet, sekaligus sebagai pengenyal makanan (Jansen, Immanuel, Labora 2010: 522).

Ikan asin adalah salah satu jenis makanan yang melewati proses pengawetan. Ikan merupakan sumber protein hewani yang bermutu tinggi. Harganya pun relatif murah dibandingkan dengan daging. Keunggulan lain dari ikan yaitu ikan lebih mudah disajikan dan dapat diterima oleh seluruh lapisan masyarakat. Ikan juga mempunyai kelemahan/kekurangan, yaitu kondisi ikan yang mudah membusuk dan rusak, untuk menghindari hal tersebut perlu dilakukan proses pemasakan dan pengawetan. Cara yang dapat dilakukan dalam proses 
pengawetan dapat dibedakan menjadi dua golongan, yaitu cara tradisional dan cara modern. Pengawetan cara tradisional bertujuan mengurangi kadar air yang terdapat pada daging ikan, agar bakteri tidak berkembang. Banyak cara yang bisa dilakukan dalam proses pengawetan tradisonal, yaitu penggaraman dan pengasapan. Ciri khas yang menonjol dari pengawetan secara tradisional yaitu jenis dan mutu bahan baku serta bahan pembantu yang sangat bervariasi, dan komposisi lingkungan yang sulit dikontrol. Jenis dan cara pengawetan yang beragam menyebabkan produk yang dihasilkan mempunyai daya awet yang berbeda sehingga dapat menurunkan nilai ikan asin dipasaran. Banyak produsen menambahkan zat aditif atau zat pengawet kimia untuk menyiasati keadaan tersebut, salah satunya boraks. Para pedagang menambahkan bahan pengawet yang bisa berupa boraks ataupun formalin dengan tujuan untuk meningkatkan nilai jual dan kualitas dari ikan asin. Peraturan Menteri Kesehatan Republik Indonesia Nomor. 1168/Menkes/Per/X/1999 tentang Perubahan Atas Peraturan Menteri Kesehatan Nomor 722/Menkes /Per /IX/ 1988 tentang Bahan Tambahan Makanan boraks merupakan salah satu bahan tambahan yang dilarang digunakan dalam makanan.

Penilaian organoleptik atau penilaian sensorik merupakan suatu cara penilaian yang paling primitif (Susiwi, 2009: 2). Penerimaan dan pemahaman konsumen adalah tujuan dari uji ini, maka uji organoleptik yang menggunakan panelis (pencicip yang telah terlatih). Uji organoleptik bertujuan untuk mengetahui seberapa teliti masyarakat dalam memilih ikan asin yang akan dikonsumsi. Uji organoleptik yang dinilai adalah warna, tekstur, dan aroma.

dapat dilihat pada tabel 1 dan gambar 1 sebagai berikut.
Berdasarkan uraian latar belakang diatas maka perlu dilakukan pengujian terhadap bahan pangan khususnya ikan yang diawetkan dalam bentuk ikan asin terhadap kandungan boraks, hal ini penting untuk menjaga kesehatan dan keamanan masyarakat.

\section{METODE PENELITIAN}

Pendekatan yang digunakan dalam penelitian adalah pendekatan deskriptif kualitatif. Metode penelitian kualitatif adalah penelitian yang bermaksud untuk memahami fenomena tentang apa yang dialami oleh subjek penelitian misalnya perilaku, persepsi, motivasi, tindakan, dll (Lexi J. Moleong, 2012: 6).

Pengambilan sampel ikan asin dilakukan pada 3 (tiga) lokasi pasar yang berbeda. Sedangkan uji organoleptik dilakukan pada masyarakat (20 ibu rumah tangga berumur 30-40 tahun dan 10 mahasiswa). Tempat analisis kandungan boraks pada ikan asin dan Uji organoleptik panelis terhadap kualitas ikan asin dilakukan di laboratorium kampus IKIP PGRI Madiun dan di Desa Klampisan Kecamatan Geneng Kabupaten Ngawi. Waktu penelitian yaitu bulan Februari-Juni 2014.

Teknik pengumpulan data dalam penelitian untuk uji borak dengan analisis volumetri yaitu titrasi asam basa untuk menentukan kadar boraks yang terkandung dalam ikan asin dan untuk uji organoleptik dengan kuisioner (angket) yang bertujuan untuk mengetahui tingkat pengetahuan dan kepekaan masyarakat terhadap ikan asin sehat dan ikan asin yang mengandung boraks terhadap warna, tekstur, dan aroma ikan asin.

\section{HASIL PENELITIAN}

\section{Analisis Boraks pada Ikan Asin}

Hasil uji kadar boraks pada ikan asin menggunakan metode titrasi volumetri 
Tabel 1. Hasil uji kadar boraks pada ikan asin menggunakan metode titrasi volumetri.

\begin{tabular}{|c|c|c|c|c|c|}
\hline No & Perlakuan & $\begin{array}{c}\text { Berat } \\
\text { Sampel } \\
\text { (gr) }\end{array}$ & $\begin{array}{c}\text { Berat } \\
\text { Boraks } \\
(\mathbf{g r})\end{array}$ & $\begin{array}{c}\text { Kadar } \\
\text { Boraks } \\
(\mathbf{\%})\end{array}$ & $\begin{array}{c}\text { Nilai } \\
\text { Organoleptik }\end{array}$ \\
\hline 1 & A1 & 5 & 0,1115 & 2,2300 & 84,3 \\
\hline 2 & A2 & 5 & 0,1015 & 2,0300 & 76,3 \\
\hline 3 & A3 & 5 & 0,0955 & 1,9100 & 71,7 \\
\hline 4 & B1 & 5 & 0,086 & 1,7200 & 59,4 \\
\hline 5 & B2 & 5 & 0,0605 & 1,2100 & 74,8 \\
\hline 6 & B3 & 5 & 0,0825 & 1,6500 & 71,1 \\
\hline 7 & C1 & 5 & 0,0765 & 1,5300 & 72,9 \\
\hline 8 & C2 & 5 & 0,1845 & 3,6900 & 72,6 \\
\hline 9 & C3 & 5 & 0,07 & 1,4000 & 64,7 \\
\hline
\end{tabular}

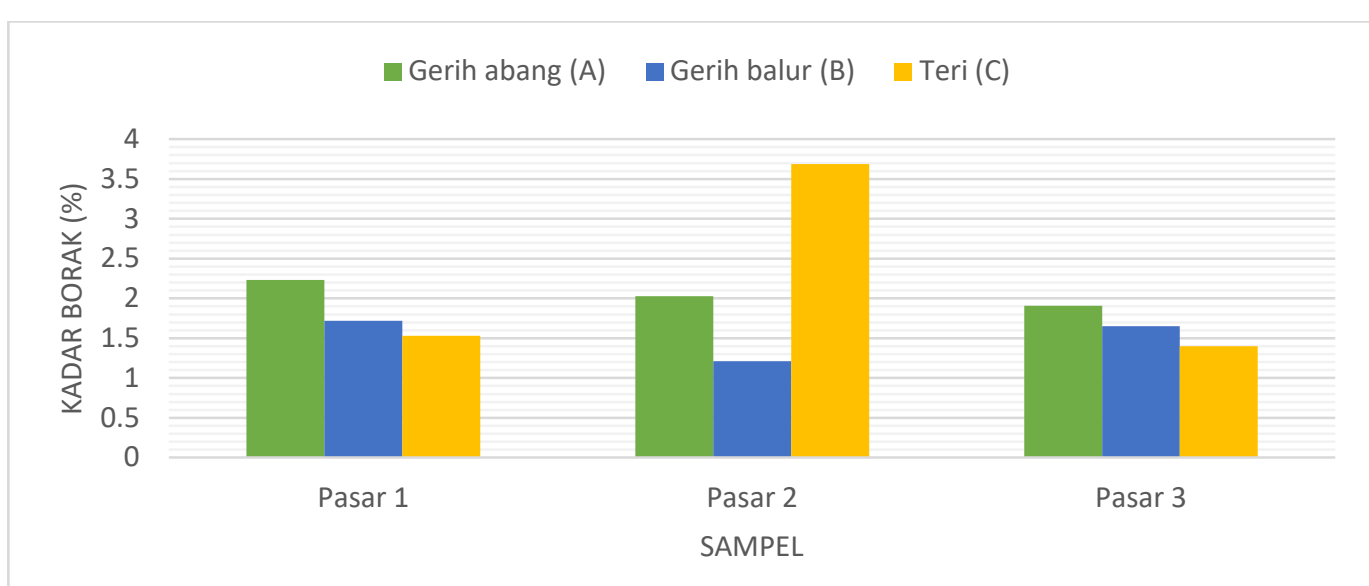

Gambar 1. Histogram Analisis kadar boraks pada ikan asin.

Berdasarkan tabel 1 dan gambar.1 di atas kadar boraks tertinggi terdapat pada ikan asin jenis teri (C2) yaitu 3,6900\% dengan nilai organoleptik sebanyak 72,6 dan penggunaan boraks dengan kadar terendah pada ikan asin jenis gerih balur (B2) yaitu1,2100\% dengan nilai organoleptik sebanyak 74,8 , jadi besarnya kandungan boraks pada asin tidak selalu sama besar dengan nilai organoleptik dari masyarakat, hal ini dibuktikan oleh ikan asin jenis gerih abang dari pasar (A1) dengan kadar boraks $2,2300 \%$ yang kadarnya tidak terlalu tinggi tetapi memiliki nilai organoleptik tertinggi dibandingkan ikan asin jenis lainnya yaitu sebesar 84,3. Kandungan kadar boraks pada ikan asin berbeda-beda antara pedagang satu dan lainnya atau antara pasar satu dengan pasar yang lainnya Hal ini disebabkan pedagang menerima pasokan ikan asin dari produsen ikan asin yang berbeda-beda. Selain itu penyebab perbedaan kadar boraks juga bisa disebabkan para pedagang menambahkan sendiri boraks pada ikan asin, hal ini dibuktikan seringnya dijumpai ikan asin yang masih dalam keadaan basah pada saat dijual, seharusnya apabila ikan asin tersebut melalui proses pengawetan tradisional ikan asin telah melewati proses penjemuran sehingga tekstur ikan asin tersebut kering dan atau rapuh/mudah patahdan tidak basah. 


\section{Uji organoleptik}

a. Uji Warna

Hasil prosentasi penelis terhadap warna ikan asin pada uji organoleptik dapat dilihat pada gambar 2 sebagai berikut.

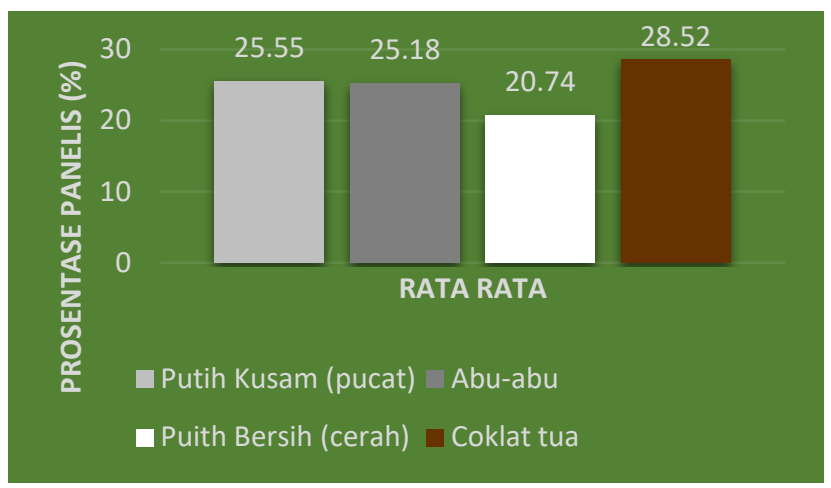

Gambar 2. Hasil uji organoleptik warna pada ikan asin

Berdasarkan gambar 2 di atas bahwa dari sampel ikan asin lebih banyak memilih ikan asin yang berwarna coklat tua yaitu dengan jumlah rata-rata $28,52 \%$, hal ini dikarenakan menurut panelis ikan asin yang berwarna coklat tua berkualitas baik dibandingkan warna lain, selain itu ikan asin jenis teri mahal harganya dibandingkan jenis ikan asin lain. Warna ikan asin yang kurang disukai oleh masyarakat yaitu ikan asin dengan warna putih bersih (cerah) sebesar 20,74\%, konsumen kurang menyukai ikan asin yang berwarna abu-abu karena menurut mereka ikan asin tersebut kurang menarik untuk dibeli dan dikonsumsi, selain itu ikan asin yang berwarna abu-abu jarang mereka temui di pasaran.

\section{b. Uji Tekstur}

Hasil prosentasi panelis terhadap tekstur ikan asin pada uji organoleptik dapat dilihat pada gambar 3 sebagai berikut.

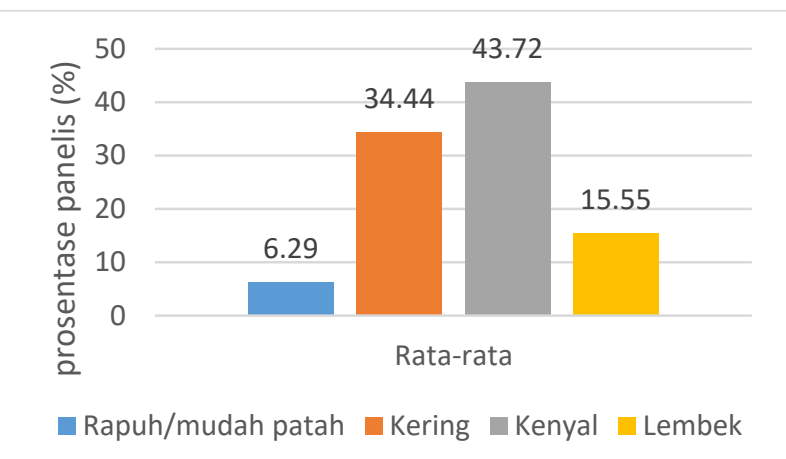

Gambar 3. Hasil uji organoleptik tekstur pada ikan asin

Berdasarkan hasil penilaian panelis tekstur ikan asin yang paling disukai yaitu pada ikan asin yang bertekstur kenyal dengan jumlah rata-rata 43,70\%. Tekstur ikan asin yang kenyal menunjukan ikan asin yang banyak mengandung bahan kimia, boraks salah satunya. Semakin kenyal tekstur ikan asin semakin banyak kandungan borkasnya, hal ini didukung oleh pernyataan Alsuhendra dan Ridawati (2013: 189) ciri-ciri makanan yang mengandung boraks (mi basah, bakso dan lontong) salah satunya bertekstur kenyal. Tekstur ikan asin yang kurang disukai masyarakat adalah ikan asin dengan tekstur rapuh dan mudah patah 
yaitu dengan jumlah rata-rata $6,29 \%$. Tekstur ikan asin yang rapuh/mudah patah asin yang berkualitas baik, karena telah melewati proses pengawetan secara tradisional melalui penggaraman dan penjemuran pada matahari secara langsung, tetapi kebanyakan masyarakat kurang

\section{c. Uji Aroma}

Hasil prosentasi penelis terhadap aroma ikan asin pada uji organoleptik dapat dilihat pada gambar 4 sebagai berikut. sebenarnya ikan

menyukai tekstur rapuh/mudah patah karena pada saat dimasak ikan asin tersebut hancur sehingga kurang tertarik untuk mengkonsumsi setelah matang.

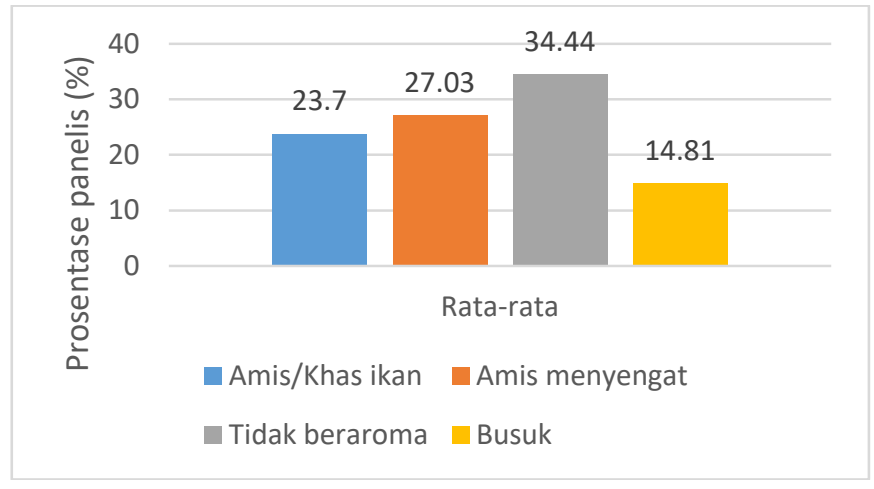

Gambar 4. Uji organoleptik aroma pada ikan asin

Berdasarkan gambar 4 di atas dapat diamati sampel ikan asin menurut panelis lebih banyak memilih ikan asin yang tidak beraroma, yaitu dengan jumlah rata-rata $34,44 \%$ hal ini dikarenakan menurut panelis ikan asin yang tidak beraroma itu tidak mengandung bahan kimia yang berbahaya bagi tubuh.
Sedangkan ikan asin yang kurang disukai panelis yaitu ikan asin yang beraroma busuk dengan jumlah rata-rata $14,81 \%$. Alasan konsumen kurang menyukai aroma busuk karena menurut mereka ikan asin tersebut sudah rusak dan tidak layak konsumsi.

\section{Data Nilai Panelis terhadap Uji Organoleptik Ikan Asin}

Data nilai panelis terhadap uji orgaoleptik pada ikan asin dapat dilihat pada tabel 2 sebagai berikut.

Tabel 2 Hasil uji Organoleptik Ikan Asin pada Panelis

\begin{tabular}{|c|c|c|c|c|c|c|c|}
\hline \multirow{2}{*}{ Sampel } & \multicolumn{2}{|c|}{ Warna } & \multicolumn{2}{c|}{ Tekstur } & \multicolumn{2}{c|}{ Aroma } & \multirow{2}{*}{ Nilai } \\
\cline { 2 - 7 } & Skor & Bobot & Skor & Bobot & Skor & Bobot & \\
\hline A1 & 99 & 30 & 60 & 40 & 102 & 30 & 84,3 \\
\hline A2 & 96 & 30 & 58 & 40 & 81 & 30 & 76,3 \\
\hline A3 & 76 & 30 & 72 & 40 & 67 & 30 & 71,7 \\
\hline B1 & 76 & 30 & 51 & 40 & 94 & 30 & 59,4 \\
\hline B2 & 75 & 30 & 76 & 40 & 73 & 30 & 74,8 \\
\hline B3 & 84 & 30 & 66 & 40 & 65 & 30 & 71,1 \\
\hline C1 & 51 & 30 & 78 & 40 & 88 & 30 & 72,9 \\
\hline C2 & 56 & 30 & 84 & 40 & 74 & 30 & 72,6 \\
\hline C3 & 52 & 30 & 80 & 40 & 57 & 30 & 64,7 \\
\hline
\end{tabular}


Tabel 2 diatas menunjukkan sampel yang mendapatkan respon terbanyak dari panelis dilihat dari aspek warna, tekstur dan aroma ikan asin adalah pada sampel A1 (Gerih abang di pasar 1) dengan nilai 84,3 sedangkan jenis ikan asin yang mendapatkan nilai terendah dari panelis dilihat dari aspek warna, tekstur, dan aroma adalah sampel B1 (Gerih balur di pasar 1)

\section{Kesimpulan}

Sampel ikan asin dengan jenis gerih abang, gerih balur dan teri yang diperoleh dari 3 pasar (Pasar Besar Ngawi, Pasar Besar Madiun dan Pasar Pojok) menunjukan seluruh sampel mengandung zat kimia yang berbahaya bagi tubuh, yaitu boraks. Kandungan kadar boraks tertinggi terdapat pada sampel C2 dengan jenis ikan asin teri dari pasar Ngawi dan kandungan kadar boraks terendah terdapat pada sampel B2 dengan jenis ikan asin gerih balur dari pasar Ngawi.

Uji organoleptik pada ikan asin yang positif mengandung boraks memiliki ciri-ciri berwarna putih cerah

\section{DAFTAR PUSTAKA}

Agus Irawan. 1997. Pengawetan Ikan \& Hasil Perikanan. Solo: Aneka.

Ait Maryani \& Ida Nuraeni. 2010. Penggunaan Zat Additive Alami Dan Non Alami Di Desa Situ Udik Dan Desa Cimanggu-1 Kecamatan Cibitung Kabupaten Bogor. Jurnal Penyuluahan Pertanian, (Online), Vol. 5, No. 1, Hal. 16-23. (http://stppbogor.ac.id/userfiles/file/02Air\%20edited:pdf). (Diunduh 27 Februari 2014).

Askuri. 2008. Peningkatan Kemandirian Belajar dengan Metode Praktikum Siswa Kelas V SD Randu dongkal Tahun Pelajaran 2007/2008. Skripsi dengan nilai 59,4. Jadi apabila konsumen ingin membeli ikan asin di pasaran disarankan untuk membeli ikan asin jenis gerih abang karena menurut panelis selaku konsumen ikan asin jenis ini layak untuk dikonsumsi dibandingkan jenis ikan asin lain (gerih balur dan teri).

dan bersih, tidak beraroma khas ikan (amis) dan bertekstur keras/kenyal sehingga tidak mudah rusak/hancur. Uji organoleptik yang dilakukan oleh panelis dengan indikator penilaian warna, tekstur dan aroma respon tertinggi pada ikan asin dengan jenis gerih abang (A1) dari pasar Madiun yang berarti ikan asin tersebut layak untuk dikonsumsi sedangkan ikan asin kurang disukai masyarakat yaitu ikan asin jenis gerih balur (B1) dari pasar Madiun yang berarti ikan asin tersebut kurang layak untuk dikonsumsi menurut panelis selaku konsumen.

Albert R. Reo. 2011. Pengaruh Perbedaan Konsentrasi Larutan Garam dan Lama Pengeringan Terhadap Mutu Ikan Layang Asin dengan Kadar Garam Rendah. Pacific Journal (Online), Vol. 2, No. 6, Hal. 11181122.(http://PengaruhPerbedaanKo nsentrasiLarutan-

Garam.ac.id/userfiles/file/02edited:pdf). (Diunduh 27 Februari 2014).

Alsuhendra, Ridawati. 2013. Bahan Toksik dalam Makanan. Bandung: PT. Remaja Rosda Karya

Budiyanti Wiboworini. 2009. Gizi dan Kesehatan. Klaten: PT. Macanan Jaya Cemerlang 
Cholid Narbuko dan Abu Achmadi. 2010. Metodologi Penelitian. Jakarta: Bumi Aksara.

Departemen Gizi dan Kesehatan Masyarakat. 2012. Gizi dan Kesehatan Masyarakat. Jakarta: PT. Raja Grafindo Persada.
Endang Triastuti, Fatimawali \& Max Revolta John Runtuwene. 2013. Analisis Boraks pada Tahu yang Diprodukdi di Kota Manado. Jurnal Ilmiah Farmasi (Online), Vol 2, No. 01, Hal. 69-74. (Diunduh 24 Maret 2014). 